\title{
Potential Sources of Genetic Resistance in Lactuca spp. to the Lettuce Aphid, Nasanovia ribisnigri (Mosely) (Homoptera: Aphididae)
}

\author{
James D. McCreight ${ }^{\mathbf{1}}$ \\ U.S. Department of Agriculture, Agricultural Research Service, 1636 \\ E. Alisal Street, Salinas, CA 93905
}

Additional index words. currant-lettuce aphid, germplasm, Lactuca perennis, Lactuca saligna, Lactuca sativa, Lactuca serriola, Lactuca virosa, red aphid

\begin{abstract}
Lettuce aphid, Nasanovia ribisnigri (Mosely) (Homoptera: Aphididae), is an economically important pest of lettuce (Lactuca sativa $\mathbf{L}$.). High-level resistance found in a wild relative, Lactuca virosa $L$. accession PIVT 280, is conditioned by the $\mathrm{Nr}$ gene, which has been transferred to European cultivars and is being commercially transferred to U.S.-adapted cultivars. New sources of resistance to guard against possible resistancebreaking strains of lettuce aphid were sought in a greenhouse screening of 1203 accessions of lettuce, which included 1047 accessions of $L$. sativa $L$., seven accessions of Lactuca perennis L., 18 accessions of Lactuca saligna $L$., 125 accessions of $L$. serriola $L$., and six accessions of $L$. viros $a$. Two new and potentially unique sources of resistance to lettuce aphid were found in $L$. serriola accession PI 491093 and $L$. virosa accession PI 274378. The genetic relationship of resistance in PI 491093 and PI 274378 with that in PIVT 280 remains to be determined.
\end{abstract}

Lettuce aphid (Nasonovia ribisnigri Mosley) has affected lettuce (Lactuca sativa L.) production in Europe since the 1970s and became a serious problem on lettuce in British Columbia, Canada, in 1981 (Forbes and MacKenzie, 1982). It was recognized as an economically important pest in the United States when it appeared in the Salinas Valley, $\mathrm{CA}$, in 1998 and has since been found in all of the lettuce production districts of Arizona and California (Chaney, 1999; Palumbo, 2000). It appeared in New Zealand in 2002 and spread throughout the country by 2003 (Stufkens et al., 2002, 2004; Stufkens and Teulon, 2003). From there it spread throughout Tasmania in 2004 (Stufkens et al., 2002, 2004) and appeared in Australia in 2004 (Anonymous, 2004).

Lettuce aphid may colonize lettuce at any time from the seedling stage of growth onward. Lettuce aphid-infested lettuce is not marketable. High numbers of lettuce aphids per plant can deform heads and change leaf color. Lettuce aphid is also capable of trans-

\footnotetext{
Received for publication 4 Dec. 2007. Accepted for publication 25 Mar. 2008.

This research was supported in part by a grant from the California Lettuce Research Board.

Mention of a trade name, proprietary product, or specific equipment does not constitute a guarantee or warranty by the USDA and does not imply its approval to the exclusion of other products that may be suitable.

Thanks to Patti Fashing, Adam Vanarsdall, Salvador Plasencia, Enrique Lopez, and Jason Ortiz for technical assistance in the greenhouse tests.

${ }^{1}$ To whom reprint requests should be addressed; e-mail james.mccreight@ars.usda.gov
}

mitting virus diseases, including Cucumber mosaic virus and Lettuce mosaic virus, to lettuce (Blua, 1997).

The lettuce aphid's propensity for colonizing the young (core) leaves makes it virtually impossible to control with foliarapplied insecticide treatments during head maturation (Liu, 2004). It has also been demonstrated to have resistance to several insecticides (Barber et al., 1999; Stufkens and Wallace, 2004). Ultralow oxygen treatment has shown efficacy for eradicating lettuce aphid during postharvest treatment (Liu, 2005), but such treatment adds to the production costs of lettuce and does not eliminate the aphids from the product. Genetic, host plant resistance to this pest is an economical and environmentally desirable means for controlling lettuce aphid infestation of lettuce (Painter, 1980).

Complete and partial types of resistance to lettuce aphid have been described in Lactuca virosa L., a wild, distant relative of cultivated lettuce (Eenink and Dieleman, 1983). Complete resistance was the result of a single gene $(\mathrm{Nr})$ that was partially dominant in segregating $\left(\mathrm{F}_{2}\right)$ families from resistant $L$. virosa $\times$ susceptible $L$. virosa crosses but dominant after introgression to cultivated lettuce, L. sativa (Eenink et al., 1982; Eenink and Dieleman, 1983). Partial resistance to lettuce aphid in $L$. virosa was the result of a recessive allele, $n r$, at the same locus (Eenink and Dieleman, 1983).

Tolerance to lettuce aphid has not been reported in lettuce. Tolerance, the ability to repair, recover, or withstand infestation damage from insects (Painter, 1980), is not desirable for commercial lettuce production as it allows levels of infestation unacceptable in the marketplace.

Transfer of complete resistance in $L$. virosa accession PIVT 280 to cultivated lettuce has resulted in the release of lettuce aphid-resistant cultivars, e.g., Dynamite (Arend et al., 1999). This resistance is highly effective against California strains of lettuce aphid; eight resistant lines and cultivars had mean numbers of less than two aphids per plant 21 d postinfestation (Liu and McCreight, 2006). In the same test, mean numbers of aphids per plant on 13 lettuce cultivars representing the four $L$. sativa cultivar groups commercially important in the United States (Lebeda et al., 2007; Mikel, 2007) ranged from 11 to 53 (Liu and McCreight, 2006).

The increased importance of lettuce aphid to lettuce production worldwide, particularly in Arizona and California, coupled with the potential for widespread use of the $\mathrm{Nr}$ gene raised concern for the development of resistance-breaking biotypes of lettuce aphid (Arend, 2003). This survey of the USDAARS exotic lettuce (L. sativa) and wild related species (L. perennis, L. saligna, $L$. serriola, and $L$. virosa) germplasm collection at Salinas, CA (McGuire et al., 1993) revealed two potentially unique sources of genetic resistance to lettuce aphid.

\section{Materials and Methods}

Plant materials. Exotic lettuce and wild related species accessions in the USDA-ARS lettuce germplasm collection at Salinas, CA, were evaluated for resistance to lettuce aphid. Of these 1204 accessions, 839 had unique U.S. PI numbers; 183 PI had more than one subaccession based on various criteria, e.g., seed color, identified at Salinas during various field and greenhouse tests over many years; the numbers of subaccessions ranged from two (97 accessions) to 13 (one accession). 'Salinas' served as the susceptible control in all initial screening and follow-up tests. 'Barcelona', which carries the $N r$ gene from PIVT 280 (Rijk Zwaan USA, Salinas, CA), served as the resistant control in all but two tests.

The test protocols changed over the course of the 125 tests. Initially, seeds of each entry were sown in coarse, washed sand in $10 \mathrm{~cm} \times 10 \mathrm{~cm} \times 10-\mathrm{cm}$ plastic pots and covered with Tencate Mirafi ${ }^{\circledR}$ geosynthetic fabric (http://www.tencate.com/) through emergence. Seedlings were transplanted at the one to two true leaf stage into $6.4 \mathrm{~cm} \times 6.4$ $\mathrm{cm} \times 6.4-\mathrm{cm}$ plastic pots in the first 56 and final nine tests. In the intervening 60 tests, seeds of each entry were sown into plastic, nursery-grade tray inserts with 12 cells $(3 \times$ 4 configuration; individual cell dimensions were $\approx 3 \mathrm{~cm} \times \approx 4 \mathrm{~cm} \times \approx 6 \mathrm{~cm}$ deep; product ST-I-0812; T.O. Plastics, Clearwater, MN) filled with a 1 potting mix : 1 sand mixture (by volume). Seedlings were thinned to one per cell at the one to two true leaf stage of growth. The mean number of plants per accession was 11 and ranged from three (four accessions resulting from poor germination) to 24 (one 
accession). Plants were watered daily with Peters ${ }^{\circledR}$ Excel 15-5-15 Cal-Mag (Scotts-Sierra Horticultural Products, Marysville, Ohio; $<$ http://the-scotts-exchange.com/_documents/ WSF/PetersExcel/H4045.pdf $>$ ) to deliver $100 \mathrm{mg} \cdot \mathrm{L}^{-1} \mathrm{~N}$.

Lettuce aphid strain and test protocols. Lettuce aphids were collected from lettuce grown in a field at the USDA-ARS research station, Salinas, CA, in 2001 and reared on lettuce plants, usually 'Parris Island' and 'Salinas', in large, insect-proof, screened cages in a greenhouse. The colony was periodically supplemented with field-collected lettuce aphids through the duration of the testing to ensure representation of populations in commercial fields and on occasion was completely reestablished when contaminated by parasitic or predatory insects.

The tests were done in a greenhouse over a 6-year period (2002 to 2007). Temperature and daylength conditions were in constant seasonal flux. Greenhouse temperatures were moderated with cooling and heating, but ranged from night lows of $\approx 4$ and $10{ }^{\circ} \mathrm{C}$ to daytime highs of $\approx 20$ to $40{ }^{\circ} \mathrm{C}$ in winter and summer, respectively. Daylength was not supplemented with artificial lighting and ranged from $\approx 9.7 \mathrm{~h}$ (winter solstice) to $\approx 14.7 \mathrm{~h}$ (summer solstice).

Infested plants were placed in insectproof cages $(\approx 63 \mathrm{~cm} \times 63 \mathrm{~cm} \times 63 \mathrm{~cm})$. The first 56 tests (plants in individual pots as described previously) were arranged in randomized complete blocks comprised of 10 replications, one replication per cage. Each replication included up to 14 entries plus the two controls arranged in a grid pattern $\approx 10 \mathrm{~cm}$ apart. In the subsequent 60 tests, the entries (one accession per 12-pack insert) were randomly placed in cages in a grid pattern, typically as many as eight entries per cage. The mean number of accessions per test was 10 and ranged from one to 16 plus controls. The entries for a particular test would thus be placed in one, two, or three adjacent cages.

Two infestation protocols were used, controlled and mass. Controlled infestations were done in the first 31 (247 accessions; 334 including subaccessions) and the final nine tests using nymphs $24 \mathrm{~h}$ old or less, five nymphs per plant. Aphids were transferred en masse from the colony to an aphid-free, susceptible lettuce plant or to detached lettuce leaves placed in a flask of water and then placed in an insect-proof cage or plastic box, respectively, for $24 \mathrm{~h}$. The nymphs were individually placed on the test plants using an artist brush. In the subsequent four tests (19 accessions; 39 including subaccessions), half the plants were infested using the controlled protocol and half were mass-infested. The mass protocol used aphids of all ages taken directly from the source colony on leaf pieces and placed on or adjacent to each test plant. After observing no differences in the aphid categories between the two inoculation protocols for any of the accessions in these four tests (data not shown), mass infestations were used in the subsequent 81 tests (573 accessions; 831 including subaccessions).
Total numbers of aphids (nymphs + alatae) were counted $14 \mathrm{~d}$ postinfestation (dpi) in the first test, whereas in Tests 2 through 30 , counts were made up to 50 aphids; numbers exceeding 50 were noted as " $50+$ ". In the subsequent germplasm screening tests, the numbers of aphids were categorized using a 1 to 5 scale: $1=$ no aphids; $2=$ one to 10 aphids; $3=11$ to 20 aphids; $4=21$ to 30 aphids; and $5=31$ or more aphids. Infestation category was usually determined $14 \mathrm{dpi}$, two tests were evaluated $13 \mathrm{dpi}$, and three tests were evaluated $18 \mathrm{dpi}$. Determinations for six tests were redone at 21 (two tests), 26 (two tests), and 27 (two tests) dpi as a result of low numbers of aphids at $14 \mathrm{dpi}$. The second determinations in two additional tests that were infested 26 Nov. 2003 were done 56 dpi, a result of shortening days and cold temperatures during that time.

Data analysis. Most accessions were tested only once. Count data from the first 30 tests were converted to categorical scores. Categorical data were then subjected, by test, to Student's $t$ test comparisons with 'Barcelona' using JMP 5.1.2 (SAS Institute, Cary, NC). Those accessions with mean category ratings that were not statistically different from 'Barcelona' were retested in nine subsequent tests using the controlled infestation protocol where every aphid was counted as in the first test. These data were subjected to Student's $t$ test comparisons.

\section{Results and Discussion}

The mean aphid category rating for the five Lactuca species across the 116 tests was 3.8; means of the five species ranged from 3.6 to 4.3 (Table 1). Mean category rating for the lettuce aphid-susceptible 'Salinas' was 4.4 over the tests. The range in the category ratings of 'Salinas' from 2.2 to 5.0 reflects the variability in survival of lettuce aphids on highly susceptible hosts for reasons that are unknown. These data for 'Salinas' were comparable to previous data from controlled greenhouse tests of 'Salinas' and 12 other cultivars representing the various lettuce types (Liu and McCreight, 2006). In contrast, mean aphid category for the lettuce aphidresistant 'Barcelona' over the tests was 1.9 (Table 1). Its mean aphid category ranged

Table 1. Mean lettuce aphid category for 1202 PI accessions of five lettuce species, lettuce aphidsusceptible Salinas, and lettuce aphid-resistant Barcelona pooled across 116 greenhouse tests.

\begin{tabular}{lccc}
\hline Lactuca & $\begin{array}{l}\text { Number of } \\
\text { species }\end{array}$ & \multicolumn{2}{c}{ Aphid category } \\
\cline { 3 - 4 } accessions & Mean & Range \\
\hline perennis & 6 & 3.8 & $3.7-4.1$ \\
saligna & 18 & 3.6 & $2.5-5.0$ \\
sativa & 1,044 & 4.3 & $2.0-5.0$ \\
serriola & 125 & 3.8 & $2.0-5.0$ \\
virosa & 6 & 3.6 & $1.8-4.3$ \\
Salinas & 117 & 4.4 & $2.2-5.0$ \\
Barcelona & 114 & 1.9 & $1.0-3.1$ \\
\hline z1 $=$ no aphids; $2=$ one to 10 aphids; $3=11$ to 20 \\
aphids; 4=21 to 30 aphids; and $5=31$ or more \\
aphids.
\end{tabular}

from 1.0 to 3.1 , which shows that lettuce aphid can either survive or reproduce at times on cultivars derived from PIVT 280 and is consistent with previous data from controlled greenhouse tests (Liu and McCreight, 2006).

The seven L. perennis accessions were all highly susceptible with mean aphid category ratings greater than 3.5 (Table 1), whereas accessions in the other four species ranged from ratings that were comparable to 'Barcelona' to 5.0 (Table 1). Nine accessions had mean aphid category ratings that were not significantly different from 'Barcelona' (Table 2). PI 509529 (L. serriola; Test 111) was not pursued further as a potential source of resistance, although it had a mean rating of 2.5; its ratings ranged from 2 to 4 (Table 2). Six others (PI 491100, PI 491107, PI 491245, PI 491251, PI 503602, PI 509524a) proved significantly more susceptible than 'Barcelona' in two subsequent tests (data not shown) and were, therefore, not pursued further as potential sources of resistance to lettuce aphid.

No aphids survived the initial infestation of PI 491093 (L. serriola) in Test 96, but after reinfestation, all 12 plants were rated 2 (Table 2). PI 274378 (L. virosa) had a lower rating than 'Barcelona' in Test 111 (Table 2).

Five subsequent retests of PI 491093 confirmed its reaction to lettuce aphid (Table 3). Plants were individually infested with 10 aphids per plant, and every aphid was counted 16 (nas04-5) to 32 (nas04-2) dpi. PI 491093 and 'Barcelona' were not significantly different in any of the tests (Table 3 ). Their mean number of lettuce aphids for the five tests were 1.7 and 1.2, respectively, compared with 37.2 on 'Salinas'.

Two subsequent tests of PI 274378 confirmed its reaction to lettuce aphid. 'Barcelona' was not included in these tests (Table 4), but 'Salinas' was highly susceptible.

Reactions of PI 491093 and PI 274378 to other aphid species remain to be determined. Development of lettuce cultivars with broad resistance to aphids is a challenge as the known sources of resistance to important and minor aphid species are strongly speciesspecific (Reinink et al., 1995), although a given source may possess resistance to more than one species, e.g., potato aphid, Macrosiphum euphorbiae Thomas, and brown sowthistle aphid, Uroleucon sonchi L. (Reinink and Dieleman, 1989b). Resistance to green peach aphid, Myzus persicae (Sulzer), provides no resistance to lettuce aphid or potato aphid (Reinink et al., 1989). The effect of the $\mathrm{Nr}$ gene on green peach aphid is mediated by other genes, but it does not affect potato aphid or brown sowthistle aphid (Reinink and Dieleman, 1989a). Conversely, lettuce cultivars with resistance to potato aphid may be susceptible to green peach aphid, lettuce aphid, and brown sowthistle aphid (Reinink et al., 1995, 1989; Reinink and Dieleman, 1989a). Resistance to the brown sowthistle aphid did not confer resistance to the lettuce aphid or potato aphid (Reinink and Dieleman, 1989b). The $R a$ gene for resistance to lettuce 
Table 2. Aphid category means and frequency distributions for nine lettuce accessions with the mean aphid category ratings not significantly greater than Barcelona compared by test with iceberg lettuce cvs. Barcelona and Salinas ${ }^{\mathrm{z}}$.

\begin{tabular}{|c|c|c|c|c|c|c|c|c|}
\hline \multirow[b]{2}{*}{ Test entry } & \multirow[b]{2}{*}{ Species } & \multirow[b]{2}{*}{$\mathrm{n}$} & \multicolumn{6}{|c|}{ Aphid category $^{\mathrm{y}}$} \\
\hline & & & Mean & 1 & 2 & 3 & 4 & 5 \\
\hline \multicolumn{9}{|l|}{ Test 96} \\
\hline Barcelona & L. sativa & 12 & $1.4 \mathrm{a}^{\mathrm{x}}$ & 7 & 5 & 0 & 0 & 0 \\
\hline PI 491093 & L. serriola & 12 & $2.0 \mathrm{a}$ & 0 & 12 & 0 & 0 & 0 \\
\hline Salinas & L. sativa & 12 & $4.0 \mathrm{~b}$ & 0 & 0 & 1 & 10 & 1 \\
\hline \multicolumn{9}{|l|}{ Test 97} \\
\hline PI 491107 & L. sativa & 12 & $1.8 \mathrm{a}$ & 2 & 10 & 0 & 0 & 0 \\
\hline Barcelona & L. sativa & 12 & $1.9 \mathrm{a}$ & 1 & 10 & 0 & 0 & 0 \\
\hline PI 491100 & L. serriola & 12 & $2.2 \mathrm{a}$ & 0 & 10 & 2 & 0 & 0 \\
\hline Salinas & L. sativa & 11 & $4.4 \mathrm{~b}$ & 0 & 0 & 0 & 7 & 4 \\
\hline \multicolumn{9}{|l|}{ Test 106} \\
\hline Barcelona & L. sativa & 12 & $2.0 \mathrm{a}$ & 1 & 10 & 1 & 0 & 0 \\
\hline PI 491251 & L. serriola & 11 & $2.2 \mathrm{a}$ & 0 & 9 & 2 & 0 & 0 \\
\hline PI 503602 & L. sativa & 12 & $2.2 \mathrm{a}$ & 0 & 9 & 3 & 0 & 0 \\
\hline PI 491245 & L. serriola & 12 & $2.4 \mathrm{a}$ & 0 & 7 & 5 & 0 & 0 \\
\hline Salinas & L. sativa & 12 & $4.4 \mathrm{~b}$ & 0 & 0 & 2 & 3 & 7 \\
\hline \multicolumn{9}{|l|}{ Test 110} \\
\hline Barcelona & L. sativa & 12 & $1.8 \mathrm{a}$ & 3 & 9 & 0 & 0 & 0 \\
\hline PI 509524a & L. saligna & 12 & $2.2 \mathrm{a}$ & 0 & 8 & 3 & 0 & 0 \\
\hline Salinas & L. sativa & 12 & $3.9 \mathrm{c}$ & 0 & 0 & 1 & 11 & 0 \\
\hline \multicolumn{9}{|l|}{ Test 111} \\
\hline PI 274378 & L. virosa & 12 & $1.8 \mathrm{a}$ & 2 & 10 & 0 & 0 & 0 \\
\hline Barcelona & L. sativa & 9 & $2.1 \mathrm{ab}$ & 0 & 8 & 1 & 0 & 0 \\
\hline PI 509529 & L. serriola & 12 & $2.5 \mathrm{~b}$ & 0 & 8 & 2 & 2 & 0 \\
\hline Salinas & L. sativa & 12 & $3.7 \mathrm{c}$ & 0 & 1 & 2 & 2 & 2 \\
\hline
\end{tabular}

${ }^{\mathrm{z}} \mathrm{A}$ total of 1214 accessions were tested in 116 greenhouse tests.

${ }^{\mathrm{y}} 1=$ no aphids; $2=$ one to 10 aphids; $3=11$ to 20 aphids; $4=21$ to 30 aphids; and $5=31$ or more aphids ${ }^{x}$ By test, mean values followed by the same letter are not significantly different. Number of plants classified in the respective category.

Table 3. Mean numbers of lettuce aphid nymphs on L. serriola accession PI 491093 and iceberg lettuce cvs. Barcelona and Salinas in five greenhouse tests at different days postinfestation (dpi).

\begin{tabular}{lcccrr}
\hline & \multicolumn{5}{c}{ Mean number of aphids } \\
\cline { 2 - 6 } Entry & $04-1(28)$ & $04-2(32)$ & $04-3(28)$ & $04-4(16)$ & $04-5(21)$ \\
\cline { 2 - 6 } & $4.5 \mathrm{a}^{\mathrm{z}}$ & $0.8 \mathrm{a}$ & $2.1 \mathrm{a}$ & $0.4 \mathrm{a}$ & $0.5 \mathrm{a}$ \\
PI 491093 & $3.8 \mathrm{a}$ & $0.0 \mathrm{a}$ & $0.0 \mathrm{a}$ & $2.2 \mathrm{a}$ & $0.0 \mathrm{a}$ \\
Barcelona & $21.4 \mathrm{~b}$ & $24.0 \mathrm{~b}$ & $68.4 \mathrm{~b}$ & $30.2 \mathrm{~b}$ & $42.1 \mathrm{~b}$ \\
\hline
\end{tabular}

${ }^{\mathrm{z}}$ Within columns, means followed by the same letter are not significantly different $(P=0.01)$.

Table 4. Mean numbers of lettuce aphid nymphs on L. virosa accession PI 274378 and iceberg lettuce cv. Salinas in two greenhouse tests at different days postinfestation (dpi).

\begin{tabular}{|c|c|c|c|c|}
\hline \multirow[b]{3}{*}{ Entry } & \multicolumn{4}{|c|}{ Mean number of lettuce aphids } \\
\hline & \multicolumn{2}{|c|}{$\begin{array}{c}\text { Test nas04-10 } \\
\text { (28) }\end{array}$} & \multicolumn{2}{|c|}{$\begin{array}{c}\text { Test nas04-11 } \\
\text { (32) }\end{array}$} \\
\hline & Mean & $\mathrm{n}$ & Mean & $\mathrm{n}$ \\
\hline PI 274378 & $0.0 \mathrm{a}^{\mathrm{z}}$ & 12 & $1.2 \mathrm{a}$ & 8 \\
\hline Salinas & $29.8 \mathrm{~b}$ & 5 & $43.6 \mathrm{~b}$ & 10 \\
\hline
\end{tabular}

${ }^{\mathrm{z}}$ Within columns, means followed by the same letter are not significantly different $(P=0.01)$.

root aphid, Pemphigus bursarius L., is considered to have no effect on other aphids (Reinink et al., 1995) and was demonstrated experimentally to have no effect on the potato aphid or brown sowthistle aphid (Reinink and Dieleman, 1989a; Reinink et al., 1995). 'Dynamite' has complete resistance to lettuce aphid and considerable resistance to potato aphid, brown sowthistle aphid, and lettuce root aphid but is susceptible to glasshousepotato aphid, Aulacorthum solani (Kalt.) (Arend et al., 1999).
Lettuce aphid has become a worldwide, economically important pest of lettuce. Highlevel resistance derived from $L$. virosa accession PIVT 280 has been successfully transferred to commercial cultivars (Arend, 2003; Hand et al., 2003). PIVT 280 also possesses genetic resistance to Beet western yellows virus (Maisonneuve et al., 1991) and Mirafiori lettuce big vein virus ( $\mathrm{R}$. Hayes and W. M. Wintermantel, unpublished data). The initial successful transfer of the $\mathrm{Nr}$ gene from $L$. virosa to cultivated lettuce was a major accomplishment that provided lettuce growers with a potent means for controlling lettuce aphid. Additional genes for resistance may, however, prove invaluable to control this pest in the future after the $N r$ gene has been more widely deployed in commercial lettuce production. This evaluation revealed two potential sources of resistance to lettuce aphid for further investigation: PI 491093 (L. serriola) and PI 274378 (L. virosa). PI 491093 is susceptible to powdery mildew incited by Golovinomyces cichoracearum (D.C.) Huleta (syn. Erisyphe cichoracearum auct. p.p.; unpublished data). PI 274378 is also resistant to Mirafiori lettuce big vein virus (R. Hayes and W.M. Wintermantel, unpublished data) and powdery mildew (unpublished data). Further research is needed to determine the inheritance of their respective resistances, potential allelism with the $\mathrm{Nr}$ gene, and their mechanisms of action. Transfer of a unique gene from $L$. serriola that is a component of the primary gene pool of lettuce will likely prove easier than the initial transfer of $\mathrm{Nr}$ from $L$. virosa, which comprises the tertiary gene pool for lettuce (Lebeda et al., 2007).

\section{Literature Cited}

Anonymous. 2004. Australian Vegetable and Potato Growers Federation. Lettuce aphid outbreak update. 11 Apr. 2008. <http://www.ausveg. com.au/assets/contentitems/public/1268/ LettuceAphidFAQsConsumers.pdf $>$.

Arend, A.J.M.v.d. 2003. The possibility of Nasonovia ribisnigri resistance breaking biotype development due to plant host resistance: A literature study, p. 75-81. In: Hintum, T.J.L.v. A. Lebeda, D.A. Pink, and J.W. Schut (eds.) EUCARPIA leafy vegetables 2003. Proceedings of the EUCARPIA Meeting on Leafy Vegetables Genetics and Breeding, Noordwijkerhout, The Netherlands, 19-21 Mar. 2003. Centre for Genetic Resources, Wageningen.

Arend, A.J.M.v.d., A. Ester, and J.T.v. Schijndel. 1999. Developing an aphid-resistant butterhead lettuce 'Dynamite', p. 149-157. Eucarpia leafy vegetables '99. Palacky University, Olomouc, Czech Republic.

Barber, M.D., G.D. Moores, G.M. Tatchell, W.E. Vice, and I. Denholm. 1999. Insecticide resistance in the currant-lettuce aphid, Nasonovia ribisnigri (Homoptera: Aphididae) in the UK. Bull. Entomol. Res. 89:17-23

Blua, M.J. 1997. Vectors, p. 51-54. In: Davis, R.M., K.V. Subbarao, R.N. Raid, and E.A Kurtz (eds.). Compendium of lettuce diseases. APS Press, St. Paul, MN.

Chaney, B. 1999. Lettuce aphid update. Monterey county crop notes. University of California Cooperative Extension. Salinas, Calif. April: 1, 7.

Eenink, A.H., F.L. Dieleman, and R. Groenwold. 1982. Resistance of lettuce (Lactuca) to the leaf aphid Nasonovia ribis nigri. 2. Inheritance of the resistance. Euphytica 31:301304.

Eenink, A.H. and L.F. Dieleman. 1983. Inheritance of resistance to the leaf aphid Nasonovia ribisnigri in the wild lettuce species Lactuca virosa. Euphytica 32:691-695.

Forbes, A.R. and J.R. MacKenzie. 1982. The lettuce aphid, Nasonovia ribisnigri (Homoptera: Aphididae) damaging lettuce crops in British Columbia. Journal of Entomological Society of British Columbia 79:28-31.

Hand, P., N. Kift, S. McClement, J.R. Lynn, R. Grube, J.W. Schut, A.J.M.v.d. Arend, and D.A.C. Pink. 2003. Progress towards mapping QTLs for pest and disease resistance in lettuce, p. 31-35. In: Hintum, T.J.L.v., A. Lebeda, D.A. Pink, and J.W. Schut (eds.). EUCARPIA leafy vegetables 2003. Proceedings of the EUCARPIA Meeting on Leafy Vegetables Genetics and Breeding, Noordwijkerhout, The Netherlands, 19-21 Mar. 2003. Centre for Genetic Resources, Wageningen.

Lebeda, A., E.J. Ryder, R. Grube, I. Dolezalova, and E. Kriskova. 2007. Lettuce (Asteraceae; Lactuca spp.), p. 377-472. In: Singh, R.J. (ed.). 
Genetic resources, chromsome engineering, and crop improvement. CRC Press, New York, NY.

Liu, Y.-B. and J.D. McCreight. 2006. Responses of Nasonovia ribisnigri (Homoptera: Aphididae) to susceptible and resistant lettuce. J. Econ. Entomol. 99:972-978.

Liu, Y.B. 2004. Distribution and population development of Nasonovia ribisnigri (Homoptera: Aphididae) in iceberg lettuce. J. Econ. Entomol. 97:883-890.

Liu, Y-B. 2005. Ultralow oxygen treatment for postharvest control of Nasonovia ribisnigri (Homoptera: Aphididae) on iceberg lettuce. J. Econ. Entomol. 98:1899-1904.

Maisonneuve, B., V. Chovelon, and H. Lot. 1991. Inheritance of resistance to beet western yellows virus in lactuca-virosa L. HortScience 26:1543-1545.

McGuire, P., E. Ryder, R. Michelmore, R. Clark, R. Antle, G. Emery, R. Hannan, R. Kesseli, E. Kurtz, O. Ochoa, V. Rubatzky, and W. Waycott. 1993. Genetic resources of lettuce and Lactuca species in California. An assessment of the USDA and UC collections and recommendations for long-term security. Report No. 12. University of California Genetic Conservation Resources Program, Davis, CA.

Mikel, M.A. 2007. Genealogy of contemporary North American lettuce. HortScience 42: 489-493.

Painter, R.H. 1980. Breeding plants resistant to insects. John Wiley \& Sons, New York, NY.

Palumbo, A.D. 2000. Seasonal abundance and control of the lettuce aphid, Nasonovia ribisnigri, on head lettuce in Arizona. 2000 Vegetable Report, University of Arizona College of Agriculture 2000 and Life Sciences. 1 Apr. 2008 $<$ http://ag.arizona.edu/pubs/crops/az1177/>.

Reinink, K. and F.L. Dieleman. 1989a. Comparison of sources of resistance to leaf aphids in lettuce (Lactuca sativa L.). Euphytica 40: 21-29.

Reinink, K. and F.L. Dieleman. 1989b. Resistance in lettuce to the leaf aphids Macrosiphum euphorbiae and Uroleucon sonchi. Ann. Appl. Biol. 115:489-498.

Reinink, K., F.L. Dieleman, and R. Groenwold. 1995. Inheritance of partial resistance to the leaf aphids Macrosiphum euphorbiae and Uroleucon sonchi in lettuce. Ann. Appl. Biol. 127:413-424.
Reinink, K., F.L. Dieleman, J. Jansen, and A.M. Montenarie. 1989. Interactions between plant and aphid genotypes in resistance of lettuce to Myzus persicae and Macrosiphum euphorbiae. Euphytica 43:215-222.

Stufkens, M.A.W., S.E. Nichol, S.R. Bulman, and G.M. Drayton. 2004. Incursion of the lettuce aphid into Tasmania-Could it have blown over from New Zealand? New Zealand Plant Protection 57:340 (Abstr.)

Stufkens, M.A.W. and D.A.J. Teulon. 2003. Distribution, host range and flight pattern of the lettuce aphid in New Zealand. New Zealand Plant Protection 56:27-32.

Stufkens, M.A.W., D.A.J. Teulon, and S.R. Bulman. 2002. Nasonovia ribisnigri, a new aphid pest found on lettuces (Lactuca sativa L.) and Ribes spp. in Canterbury. New Zealand Plant Protection 55:437 (Abstr.)

Stufkens, M.A.W. and A.R. Wallace. 2004. Effectiveness and persistence of six insecticides for control of lettuce aphid on field lettuce in Canterbury, New Zealand. New Zealand Plant Protection, Volume 57, 2004. Proceedings of a conference, Hamilton, New Zealand, 10-12 Aug. 2004. p. 233-238. 